\title{
Upaya Meningkatkan Disiplin Tenaga Pendidik Melalui Penerapan Metode Penugasan
}

\author{
MOHD. TOHIR \\ Tenaga Pengajar pada Dinas Pendidikan Kabupaten Kampar \\ SMP Negeri 6 Siak Hulu \\ Email: mohdtohir@yahoo.com
}

\begin{abstract}
Teacher discipline is a requirement in implementing the learning plan in school. Teachers become the spearhead of service required to be an example and role model for learners. Examples and examples of this teacher can be seen from the discipline of teachers in implementing the work plan of teaching and learning in schools. Through classroom action research using assignment method by applying 3 cycles and data analyzed descriptively it can be proven that the assignment method for the teacher in the form of assignment of the implementation of the lesson plan by giving the award proves the gradual improvement of teacher work discipline in school.
\end{abstract}

Keywords: Discipline of educator, method of assignment

Menurut Abdi, R. (2007) bahwa budaya disiplin dikembangkan melalui pembuatan peraturan dan tata tertib sekolah. Selain itu juga Utami, U. (2016) melalui penerapan budaya semangat pagi dapat meningkatkan disiplin guru dalam melaksanakan kegiatan pembelajaran.

Dampak kedisiplinan guru mengarah kepada peningkatan hasil belajar peserta didik. Sebagaimana disampaikan oleh Arisana, A. L., \& Ismani, I. (2012) bahwa kedisiplinan Siswa berpengaruh positifdan signifikan terhadap Prestasi Belajar. Kemudian juga diteliti oleh Eros, E. (2014) bahwa ada pengaruh yang positif dan signifikan motivasi kerja guru terhadap kinerja guru. Besarnya pengaruh 61,1\% 2) ada pengaruh yang positif dan signifikan kedisiplinan kerja guru terhadap kinerja guru. Besarnya pengaruh adalah 55,9\%, 3) ada pengaruh secara simultan antara motivasi kerja guru dan kedisiplinan kerja guru dengan kinerja guru. Besarnay pengaruh 66,9 \%. Berdasarkan hasil penelitian di atas, maka direkomendasikan: 1) para guru untuk lebih meningkatkan motivasinya dalam melaksanakan tugas keseharian sebagai guru, 2) Kepala Sekolah agar mendukung dan memberikan kesempatan seluas-luasnya bagi para guru untuk mengikuti pelatihan dan kursuskursus agar kompetensi guru meningkat, 3) kepada para peneliti untuk melakukan penelitian lanjutan dengan factor-faktor lain yang mempengaruhi kinerja guru sehingga menambah wawasan yang lebih luas.

Mengenai disiplin ini, dalam kehidupan sehari-hari dikenal disiplin diri, disiplin belajar, dan disiplin kerja. Seseorang dikatakan memiliki disiplin diri yang kuat bila ia dapat mengendalikan dirinya sendiri. Kerugian akibat dilanggarnya disiplin lazimnya tidak langsung, tetapi berjangka panjang. Karena itu orang yang berdisiplin diri adalah orang yang memiliki kemampuan untuk menjangkau kedepan akibat tindakannya, bukan hanya pada akibat langsung, melainkan sampai kepada konsekuensi tingkat kedua ataupun ketiga. Demikian juga dengan disiplin belajar, yang merupakan kemampuan seseorang untuk secara teratur belajar dan tidak melakukan sesuatu yang dapat merugikan tujuan akhir dari proses belajarnya. 
Para siswa sering ada yang berprilaku sedemikian rupa hingga mendatangkan masalah bagi guru dan teman-temannya. Dan bagi guru, hal ini dapat menimbulkan masalah yang serius. Mereka tidak dapat menutup mata terhadap pelanggaran disiplin baik di dalam kelas maupun di lingkungan sekolah. Pendekatan tentang disiplin ini merupakan suatu cara baru bagi hampir semua guru. Ketika guru masuk kedalam kelas, merekasebenarnya ingin mengajar, bukan disiplin. Para guru baru kebanyakan berharap tidak akan menghadapi maslah yang menyangkut disiplin, sebab sebagai guru mereka yakin bahwa mereka kompeten dan percaya bahwa masalah disiplin tidak akan muncul. Sedangkan dilain pihak, guru yang telah berpengalaman sering menekankan perlunya membina disiplin. Dimulai dari pihak guru sendiri, sebab mereka yakin bahwa disiplin perlu ditegakkan dimanamana, sebab anak-anak disekolah tidak cukup disiplin. Sebagai guru, mereka ingin melihat agar murid belajar.

Maka Guru dalam tugasnya mendidik dan mengajar murid-muridnya adalah berupa membimbing memberi petunjuk, teladan, bantuan, latihan, penerangan, pengetahuan, pengertian, kecakapan, nilai-nilai, norma-norma, kesusilaan, kejujuran, sikap-sikap, maka ia berkewajiban juga mengarahkan siswanya agar disiplin. Dan menteransfer budaya yang baik kepada anak didiknya.

Sehingga sekolah sebagai salahsatu sarana sosialiosasi anak diharapkan mengarahkan anak agar disiplin. Dan halhal dalam mendisiplinkan anak bisa dilakukan seorang guru dengan cara memfungsionalkan prinsip-prinsip dan teori pendidikan dan bekerja sama dengan seluruh guru-guru, staf pegawai, atasan dan masyarakat sekolah. Sehingga disiplin bisa membudaya dalam pribadi peserta didik dan seluruh masyarakat sekolah.

$$
\text { Permasalahan yang tentang }
$$

pelangaran disiplin guru-guru SMP N 6 Siak Hulu antara lain: guru datang terlambat, sebagian guru tidak mengerjakan administrasi pembelajaran, guru kurang aktif, kurnag kreatif dan kurang inovatif dalam proses pembelajaran dan tidak maksimalnya guru dalam menerapkan proses belajar mengajar di kelas.

Selama ini belum ada tindakan yang dilakukan kepala sekolah terhadap guru yang kurang disiplin dalam melaksanakan pekerjaam. Pada kesempatan ini penulis tertarik mengaitkan antara kedisiplinan guru dengan masalah penugasan yang diberikan kepada guru. Melalui penugasan yang intensif dan diberikan secara berkelanjutan kepada guru serta petanggungjawabannya, maka diharapkan akan meningkatkan disiplin kerja guru.

Beberapa rujukan yang digunakan dalam penelitian ini berkaitan dengan masalah metode pembelajaran penugasan antara lain: menurut Sabriani, S. (2013) bahwa metode penugasan memiliki langkah dengan beberapa siklus antara lain: siklus melalui tahap perencanaan (plan), pelaksanaan (act), observasi (observe), refleksi (reflect). Tindakan yang dilakukan untuk memecahkan masalah penelitian adalah Langkah-langkah pembelajaran langsung terdiri dari lima tahap aktivitas yaitu (1) menyampaikan tujuan dan mempersiapkan siswa, guru menjelaskan tujuan pembelajaran khusus, informasi latar belakang pelajaran, mempersiapkan siswa untuk belajar, (2) membahas tugas dan menyampaikan hasilnya di depan kelas, (3) mendemonstrasikan pengetahuan dan keterampilan, guru mendemonstrasikan keterampilan dengan benar, atau menyajikan informasi tahap demi tahap, (4) membimbing pelatihan, guru merencanakan dan memberi bimbingan pelatihan awal, (5) Mengecek pemahaman dan memberikan umpan balik, mengecek apakah siswa telah berhasil melakukan tugas dengan baik, memberi umpan balik. (6) memberikan kesempatan untuk pelatihan lanjutan dan penerapan, guru mempersiapkan kesempatan melakukan pelatihan lanjutan, dengan perhatian khusus pada penerapan kepada situasi lebih kompleks dan

p.ISSN: $2407-800 X \quad$ e.ISSN: 2541-4356 
kehidupan sehari-hari, (7) melakukan refleksi atau membuat rangkuman dengan melibatkan siswa, (8) memberikan tugas sesuai dengan indikator yang telah dibahas.

Metode penugasan adalah penugasan dari kepala sekolah kepada guru untuk diselesaikan dan dipertanggungjawabkan, tugas yang diberikan ini menyangkut kegiatan pembelajaran dan proses belajar mengajar antara lain: mempersiapkan rencana pokok pembelajaran (RPP), mengendalikan kelas agar tenang dalam belajar dan mematuhi ketepatan waktu masuk kelas dan keluar kelas sesuai dengan aturan yang berlaku.

Disiplin kerja guru merupakan kepatuhan guru dalam melaksanakan tugas dan kewajibannya, sesuai dengan aturan yang berlaku. Ketepatan waktu dalam melaksanakan tugas dan juga mempertanggungjawabkan pekerjaan yang sudah ditugaskan pimpinan menjadi sebuah ukuran kedisiplinan kerja guru dalam melaksanakan tugasnya.

Mulyasa (2005: 113) menjelaskan agar pelaksanaan metode penugasan ini dapat berlangsung secara efektif, maka guru perlu memperhatikan langkah-langkah sebagai berikut:

1. Tugas harus direncanakan secara jelas dan sistematis

2. tugas yang diberikan harus benarbenar sudah dipahami oleh peserta didik

3. jika berupa tugas kelompok diharapkan bahwa setiap anggota kelompok dapat terlibat secara aktif

4. jika memungkinkan guru hendaknya mengontrol proses penyelesaian tugas yang diberikan

5. guru hendaknya memberikan penilaian yang proporsional terhadap tugas-tugas yang telah dikerjakan oleh peserta didik.

Untuk menyesuaikan langkahlangkah penerapan metode penugasan yang diterapkan oleh kepada sekolah kepada guru, perlu dilakukan penyesuaian antara lain: kata guru diganti dengan kepala sekolah dan kata siswa atau peserta didik diganti dengan guru.

\section{METODE}

Metode yang digunakan dalam penelitian ini adalah metode penelitian tindakan sekolah bertujuan untuk mencari pemecahan permasalahan nyata yang terjadi di kelas, sekaligus mencari jawaban ilmiah bagaimana masalah-masalah tersebut bisa dipecahkan melalui suatu tindakan perbaikan. Pendekatan yang digunakan dalam penelitian tindakan ini ialah pendekatan kualitatif.

Tindakan yang dilakukan dalam penelitian ini adalah memberikan tugas kepada guru, penugasan dari kepala sekolah kepada guru untuk diselesaikan dan dipertanggungjawabkan, tugas yang diberikan ini menyangkut kegiatan pembelajaran dan proses belajar mengajar antara lain: mempersiapkan rencana pokok pembelajaran (RPP), mengendalikan kelas agar tenang dalam belajar dan mematuhi ketepatan waktu masuk kelas dan keluar kelas sesuai dengan aturan yang berlaku. Karena keterbatasan waktu, penelitian tindakan kelas ini hanya dilaksanakan sebanyak 3 siklus masing-masing siklus dilaksanakan selama 1 minggu.

Teknik pengumpulan data dari penelitian tindakan sekolah ini adalah melalui data kualitatif yang diperoleh dari observasi, pengamatan, maupun wawancara. Analisa data yang digunakan dalam penelitian ini adalah analisa data kualitatif yang bersumber dari data primer maupun empiris. Melalui analisa data ini, dapat diketahui ada tidaknya peningkatan kemampuan kedisiplinan kerja guru dalam melaksanakan proses belajar mengajar di sekolah.

\section{HASIL}

Penelitian Tindakan Sekolah (PTS) ini dilaksanakan dalam tiga siklus. Hal ini dikarenakan keterbatasan waktu yang tersedia, serta dengan tiga siklus sudah penulis anggap cukup untuk peningkatan kedisiplinan kerja guru. Hasil penelitian menunjukkan bahwa adanya peningkatkan kedisiplinan kerja guru melalui penerapan metode penugasan. 
Hasil tersebut berdasarkan hasil tindakan dengan data sebagai berikut:

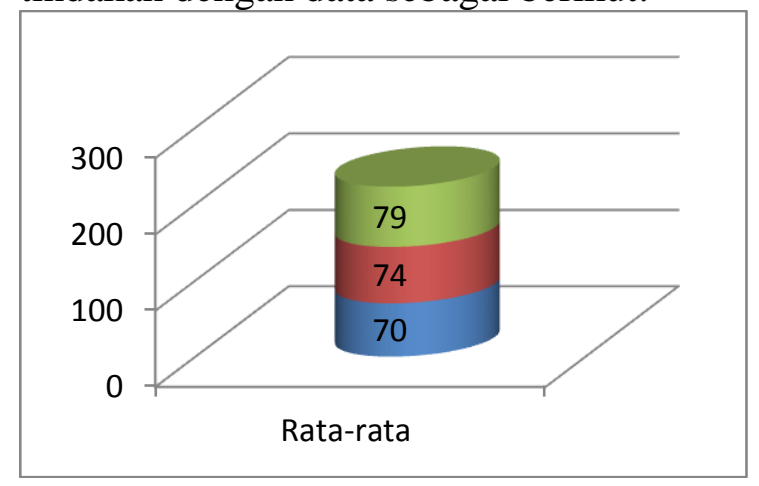

\section{PEMBAHASAN}

Melalui tindakan yang dilakukan dalam penelitian ini adalah memberikan tugas kepada guru, penugasan dari kepala sekolah kepada guru untuk diselesaikan dan dipertanggungjawabkan, tugas yang diberikan ini menyangkut kegiatan pembelajaran dan proses belajar mengajar antara lain: mempersiapkan rencana pokok pembelajaran (RPP), mengendalikan kelas agar tenang dalam belajar dan mematuhi ketepatan waktu masuk kelas dan keluar kelas sesuai dengan aturan yang berlaku. Karena keterbatasan waktu, penelitian tindakan kelas ini hanya dilaksanakan sebanyak 3 siklus masing-masing siklus dilaksanakan selama 1 minggu.

Terbukti bahwa penerapan metode penugasan dalam rangka meningkatkan kediplinan guru dalam mengajar ternyata mampu meningkatkan kediplinan guru dalam mengajar. Data yang diperoleh menunjukkan bahwa setelah dilakukan penerapan metode penugasan, maka terbukti adanya pengaruh yang ke arah yang positif dalam meningkatkan kediplinan guru dalam mengajar.

\section{SIMPULAN}

Kesimpulan yang dapat diambil melalui penelitian tindakan sekolah dengan menggunakan metode penugasan dengan menerapkan 3 siklus dan data dianalisa secara deskriptif maka dapat dibuktikan bahwa metode penugasan bagi guru dalam bentuk penugasan pelaksanaan rencana pembelajaran dengan memberikan penghargaan membuktikan terjadinya peningkatan secara bertahap disiplin kerja guru di sekolah.

\section{DAFTAR RUJUKAN}

Mulyasa E, 2005, Menjadi guru professional, menciptakan pembelajaran mampu dan menyenangkan, Bandung. PT. Remaja Rosdakarya Offset.

Abdi, R. (2007). Pengembangan Budaya Sekolah di SMAN 3 Tanjung Kabupaten Tabalong Kalimantan Selatan. Jurnal Penelitian dan Evaluasi Pendidikan, 10(2).

Arisana, A. L., \& Ismani, I. (2012). Pengaruh Kedisiplinan Siswa dan Persepsi Siswa tentang Kualitas Mengajar Guru terhadap Prestasi Belajar Akuntansi Siswa Kelas XI IPS MAN Yogyakarta II Tahun Ajaran 2011/2012. Jurnal Pendidikan Akuntansi Indonesia, 10(2).

Utami, U. (2016). Peningkatan Kedisiplinan Guru Melalui Budaya Semangat Pagi. Jurnal Penelitian Pendidikan Indonesia, 1(1).

Eros, E. (2014). Pengaruh Motivasi Dan Kedisiplinan Kerja Guru Terhadap Kinerja Guru Di SMP Negeri Kecamatan Brebes Kabupaten Brebes Jawa Tengah. Jurnal Administrasi Publik dan Birokrasi, 1(1).

Sabriani, S. (2013). Penerapan Pemberian Tugas Terstruktur disertai Umpan Balik pada Pembelajaran Langsung untuk Meningkatkan Motivasi dan Hasil Belajar Siswa (Studi Pada Materi Pokok Struktur Atom Kelas X6 SMA Negeri 3 Watampone). CHEMICA, 13(2), 39-46. 